\title{
Willingness to pay on cattle business insurance in supporting UPSUS SIWAB in Bangka Belitung Province
}

\author{
Suharyanto, Akhmad Ansyor ${ }^{*}$, and Zikril Hidayat \\ BPTP Kepulauan Bangka Belitung, Indonesian Agency for Agricultural Research and Development, \\ Pangkalpinang, 33134, Indonesia
}

\begin{abstract}
Apart from productivity problems, the implementation of beef cattle business is faced with various risks. Several risks faced by smallholder beef cattle business, such as; price, disease, feed, marketing, theft, and relationship with traders. In order to maintain the sustainability of the livestock business, breeders need a guarantee in order to continue their business. This guarantee can be in the form of livestock insurance. Cattle insurance is one of the important programs to support the livestock sector, given the important role of cattle insurance not only for breeders but for various parties. This study aims to obtain information about the willingness to pay (WTP) on cattle business insurance in Bangka Belitung Province. This research was conducted from June to October 2018 in Bangka Belitung Province. Data collection was carried out by interviewing 150 farmers as respondents as primary data. In order to strengthen this, secondary data was collected from the agricultural agency at the provincial level. The WTP value obtained shows that it is still below the value of the premium paid at this time, this indicates that farmers still want subsidies from the government for the implementation of AUTS to minimize the risk of livestock business.
\end{abstract}

\section{Introduction}

Animal husbandry development is part of the development of national resilience to achieve food security and improve the welfare of farmers/ breeders. The livestock subsector has a very important role in supporting the achievement of national food security. This is because livestock is a provider of animal food from livestock through increased production of various commodities, as well as a provider of raw materials for industry. In addition, livestock indirectly also plays a role in poverty alleviation, because livestock is a process that uses production factors from the community so that it provides remuneration to the community which will affect their income, as well as an alternative energy source and for environmental sustainability [1].

The need for beef consumption by the Indonesian population tends to continue to increase in line with the increasing population of Indonesia and public awareness of the importance of animal protein, which results in increased demand for beef from time to time [2]. The

\footnotetext{
*Corresponding author: ancuiycool@gmail.com
} 
difficulty in achieving beef self-sufficiency is partly due to the insufficient population of beef cattle. Domestic production has only been able to meet around $65 \%$, so the shortfall is met from imported products in the form of $20 \%$ frozen beef and $15 \%$ imported steers and heifers [3]. Self-sufficiency is the ability to supply $90-95 \%$ of the rest can come from imports [4]. Seeing the increasing rate of demand for beef, the government is tryingto be able to fulfill it from domestic products, while imports are made to meet its shortcomings [5]. The expected result of beef self-sufficiency is that $10 \%$ of the need is met from imports, the rest is met from local beef [6].

One of the factors causing the difficulty of achieving self-sufficiency is due to the inadequate utilization of the local and socio-economic potential of the community and the maintenance system. Based on data from the Directorate General of Livestock and Animal Health, the total population of cattle in Indonesia in 2018 was 16,432,945/ head [7]. The Bangka Belitung contribute $0.1 \%$ of the total national population in Indonesia. The total national beef production in Indonesia is 497,972 tonnes and the Bangka Belitung only contribute $0.6 \%$ of the total national production of beef in Indonesia, where the largest contribution comes from Central Bangka Regency. According to the Directorate General of Livestock and Animal Health, the level of meat consumption per capita in Indonesia in 2016 is $0.417 \mathrm{~kg}$ / capita/ year, which is low compared to other ASEAN countries.

As an acceleration of the target for the fulfillment of the domestic beef cattle population, the Ministry of Agriculture, issued a new program, namely the Special Efforts to Accelerate for Increasing Population of Cows and Buffalo (UPSUS SIWAB) [8]. UPSUS SIWAB is a continuation of the beef and buffalo self-sufficiency program which took place in 2000-2004, 2005-2009, and 2010-2014, and was continued with several programs: accelerating population increase through the program of estruss synchronization and Optimization of Artificial Insemination in 2015, and Management of Reproductive Disorders, Optimization of Reproduction and Handling of Reproductive Disorders in 2016. Due to the beef selfsufficiency program that had been launched before, it has not yet produced results [9] or has not been able to achieve the expected targets [10], while most of the local beef supply comes from smallholder farms [11]. The strategic plan of the Ministry of Agriculture 2010-2014, one of the main targets to be achieved and maintained is the achievement of sustainable beef self-sufficiency [12].

The UPSUS SIWAB program aims to increase the beef cattle population and lead to beef self-sufficiency, including the target to be achieved by 2026 [13]. This program includes two main programs, namely increasing the population through Artificial Insemination (IB) and Intensification of Natural Mating (INKA). In line with the Central Government's program, the Province of Bangka Belitung through its Regional Government is also making efforts to increase the beef cattle population so that there will be an increase in beef consumption. These programs generally aim to increase the population and productivity of cattle, by developing the potential of the existing Indonesian (national) farm. The policy of increasing the population and productivity of cattle aims to increase the capacity of supply (production) of beef nationally and to realize food sovereignty from livestock.

Apart from productivity problems, the implementation of beef cattle business is faced with various risks. There are several risks faced by smallholder beef cattle business, namely 1) price, 2) disease, 3) feed, 4) marketing, 5) theft, and 6) relationship with traders, with different main risks - different depending on the production center area of Cattle Business Insurance [14].

Cattle insurance is one of the important programs to support the agricultural sector, especially livestock, given the important role of cattle insurance not only for breeders but for various parties [15]. In its implementation, business in the field of animal husbandry is classified as having various high risks that can threaten the sustainability of the business itself. These risks can include loss of livestock and death of livestock. Biological livestock 
mortality can be caused by disease outbreaks, but can also occur such as accidents and natural disasters. This of course will cause financial losses. If breeders are not able to face and prevent risks, it will affect the continuity of their business so that in order to maintain the sustainability of the livestock business, breeders need a guarantee in order to continue their business. This guarantee can be in the form of livestock insurance. This is a good momentum to be used so that insurance in the agricultural sector can be developed in Indonesia, which is an agricultural country, one of which is based on the agricultural sector [16].

Furthermore, the government followed up on this Law with the Minister of Agriculture Regulation No. 40/ Permentan/ SR.230/ 7/ 2015 concerning agricultural insurance facilities, which contains an explanation of insurance facilities for farmers including crop insurance (food crops, horticulture and plantations) and livestock insurance (ruminant, non-ruminant and monogastric/ pseudoruminant). The purpose of this facility is to provide convenience and protection in bearing the risks of farming. Furthermore, it was also explained that this agricultural insurance is an agreement between the farmer and the insurance company to bind himself to the risk coverage of farming. This means that in agricultural insurance, farmers are the insured party, then the relevant financial institution, in this case the insurance company, is the insurer [17].

For insurance premium payments, breeders are only required to pay $20 \%$ of the existing premium value and the remaining $80 \%$ is obtained from government subsidies. The insurance premium that should be paid by the farmer is IDR 200,000, - per head/ year, but because he gets a subsidy from the government worth IDR 160,000, - then the farmer is only charged a premium of IDR 40,000, - per head/ year. The insurance price for a cow is IDR 10 million per head/ year and the coverage period is valid for one year starting from the time the insurance premium is paid, which is the obligation of the farmer.

The implementation of livestock insurance involves various parties or related agencies including the livestock service, insurance parties, breeders. The following is the mechanism for implementing livestock insurance:

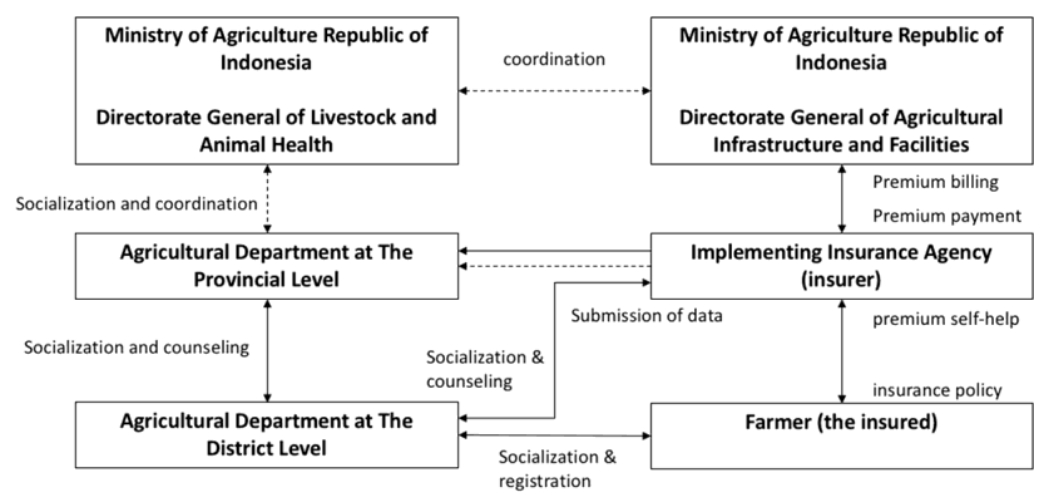

Fig.1. Animal insurance implementation mechanism [18]

Cattle livestock insurance is one of the important programs to support the agricultural sector, especially livestock. livestock insurance coverage for death is more complex than other agricultural insurance such as crop insurance. Therefore, livestock insurance in several countries such as America, Europe, Africa, and India have been implemented [19, 20, 21]. Thisis because livestock insurance that guarantees death consists of several important factors thatmust be considered, namely several stages of production in livestock, a result of losses suffered by farmers, major events that cause losses such as disease outbreaks even though this rarely occurs. In addition, moral hazard and risk selection to be insured are related to losses that will be compensated by the insurer [20], as stated by Saptana et al. [22] risk management in agriculture is important. 
Research related to agricultural insurance is also quite developed and the research focus varies. One focus of research carried out in countries that have implemented and are implementing agricultural insurance is the ability of farmers to pay insurance premiums. However, the fact is that not all farmers participate in agricultural insurance, this is related to the willingness and ability of farmers to pay insurance premiums [23, 24, 25, 26]. In general, farmers in developing countries have low household income and are reluctant to pay insurance premiums for production risks that may or may not occur [23, 26].

In Indonesia, the AUTS Scheme has been implemented in various regions in several provinces. The latest data shows that there is a tendency to increase farmer participation with an increase in the number of insured cattle (Table 1 and Figure 4 below).

Table 1. Realization of AUTS implementation in 2017-2019.

\begin{tabular}{|c|c|c|c|c|}
\hline \multirow[b]{2}{*}{ AUTS Relization } & \multicolumn{4}{|c|}{ Year } \\
\hline & $\begin{array}{c}2016 \\
\text { started } \\
31 / 07 / 2016 \\
\end{array}$ & 2017 & 2018 & $\begin{array}{c}2019 \\
\text { per } \\
31 / 07 / 2019\end{array}$ \\
\hline Premi AUTS (000.000,- IDR) & 5,405 & 18,435 & 24,000 & $15,000.12$ \\
\hline - Subsidized (80\%) & 4,324 & 14,748 & 19,200 & $12,000.16$ \\
\hline - Non subsidized (20\%) & 1,081 & 3,687 & 4,800 & $6,000,16$ \\
\hline $\begin{array}{l}\text { The number of Cattle (head) fro } \\
\text { target of } 120 \text { million heads }\end{array}$ & & & & \\
\hline - (Head) & 27,025 & 92,176 & 120,000 & 75,001 \\
\hline$-(\%)$ & 22.52 & 76.81 & 100 & 62.5 \\
\hline The Number of Farmer & 12,285 & 63,592 & 74,508 & 42,190 \\
\hline The Number of Provinces & 22 & 27 & 27 & 27 \\
\hline AUTS claim $(000.000,-$ IDR $)$ & $11,576.99$ & $30,048.16$ & $22,223.10$ & $2,531.85$ \\
\hline
\end{tabular}

Source: OJK, 2019 [27]

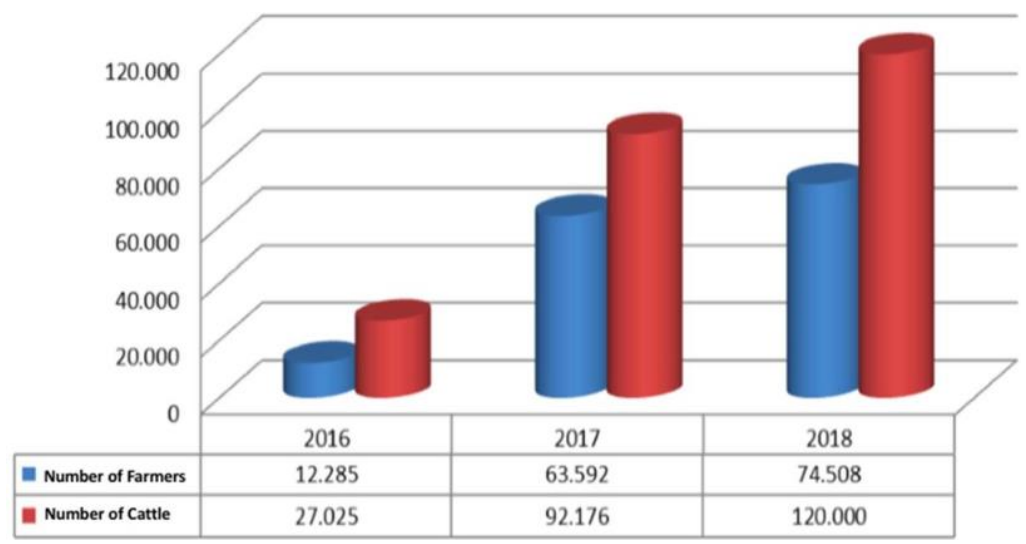

Fig. 2. AUTS growth 2017 - 2018 [27]. 
Table 2. Realization of Implementation of AUTS in Bangka Belitung Archipelago in 2017-2019

\begin{tabular}{|l|r|r|r|r|}
\hline \multirow{2}{*}{\multicolumn{1}{|c|}{ AUTS Realization }} & \multicolumn{4}{|c|}{ Year } \\
\cline { 2 - 5 } & \multicolumn{1}{|c|}{$\mathbf{2 0 1 6}$} & \multicolumn{1}{|c|}{$\mathbf{2 0 1 7}$} & \multicolumn{1}{c|}{$\mathbf{2 0 1 8}$} & \multicolumn{1}{c|}{$\mathbf{2 0 1 9}$} \\
\hline Number of Cattle (head) & 135 & 673 & 1.500 & 2.529 \\
\hline $\begin{array}{l}\text { Premi AUTS Realization } \\
\text { (000.000,- IDR) }\end{array}$ & 27.000 & 134.600 & 300.000 & 505.800 \\
\hline AUTS claim (000.000,- IDR) & 70.000 & 222.500 & 193.155 & 60.000 \\
\hline
\end{tabular}

Source: [27]

Based on Table 2, it can be seen that from the beginning the agricultural insurance program implemented in the Province of the Bangka Belitung islands shows a tendency to increase farmer participation (2016-2019). At the start of the AUTS program, the Province of Bangka Belitung Islands contributed $1.1 \%$ to the realization of the national AUTS implementation in Indonesia and experienced a very significant increase in 2019 , namely by $6 \%$.

This study aims to obtain information about the willingness to pay on cattle business insurance in supporting Special Efforts to Accelerate for Increasing Population of Cows and Buffalo in Bangka Belitung Province. Willingness to Pay (WTP) is defined as the amount of money that an individual or household is willing to pay to buy a product based on income level, risk preference and other things behind it. WTP is the maximum price that consumers are willing to pay for a product (goods or services), or it is a measure of the marginal benefits that consumers want [28]. WTP is influenced by the ability of individuals or households to pay a certain amount of money to obtain the desired product or Ability to Pay (ATP). A farmer will be willing to pay a number of insurance premiums by considering his ability or purchasing power to pay these premiums.

\section{Method}

This research was conducted from June to October 2018 in Bangka Belitung Province. Data collection was carried out by interviewing 150 farmers as respondents as primary data. In order to strengthen this, secondary data was collected from the agricultural agency at the provincial level. The observed farmers are smallholder farmers in the province of Bangka Belitung. The primary data collected is the amount of willingness to pay for the AUTS program, level of readiness of farmers to face risks. while secondary data is the amount of government budget realization in the AUTS program, then the data is processed and discussed descriptively.

\section{Results and Discussion}

The farmer's WTP value for the AUTS program is related to the breeder's desire to manage his farm risk. The greater the value that the farmer is willing to pay, this indicates that the more he cares about the risks that can befall his farm and the more willing the farmers are to minimize these risks. One indicator of the success of the AUTS program is that farmers implement AUTS by paying insurance premiums. When a farmer is willing to pay a premium, it means that the farmer has tied himself up in the farm risk coverage with Jasindo Insurance as the executing insurance. Thus, the risks that may be faced by farmers such as the risk of death due to illness, accidents, loss and childbirth can be minimized, so that the sustainability of the farm can be guaranteed, besides that when farmers pay a premium, the AUTS program can continue and is said to be successful so that the objectives of the 
program AUTS as a guarantor for the risk of crop failure can be achieved.

This concurs with [23] who said that the factor that plays an important role in influencing the willingness of farmers to pay insurance premiums is residual risks. Other factors include the size of savings, loans, business diversification, farmer demographics (knowledge and education level of farmers). The higher the level of education of farmers, the greater the willingness of farmers to participate in and pay insurance premiums [29]. There is a strong correlation between the desire to buy insurance and the level of knowledge of farmers about insurance [30]. Meanwhile, welfare in this case measured by the farmer's wealth has an effect on the desire to buy insurance which is associated with the risk of credit repayment and loss of wealth.

Table 5. Distribution of farmer's wtp on the implementation of AUTS in Bangka Belitung Province, 2018.

\begin{tabular}{|c|c|c|c|c|}
\hline \multirow{2}{*}{ No } & \multirow{2}{*}{$\begin{array}{l}\text { WTP Cluster } \\
\text { (IDR/head/year) }\end{array}$} & \multicolumn{2}{|c|}{ Number of farmers } & \multirow{2}{*}{$\begin{array}{c}\text { EWTP } \\
\text { (IDR/head/year) }\end{array}$} \\
\hline & & (people) & $(\%)$ & \\
\hline 1 & 10.000 & 18 & 12.00 & 1200.00 \\
\hline 2 & 15.000 & 18 & 12.00 & 1800.00 \\
\hline 3 & 20.000 & 16 & 10.67 & 2133.33 \\
\hline 4 & 25.000 & 26 & 17.33 & 4333.33 \\
\hline 5 & 30.000 & 14 & 9.33 & 2800.00 \\
\hline 6 & 35.000 & 10 & 6.67 & 2333.33 \\
\hline 7 & 40.000 & 6 & 4.00 & 1600.00 \\
\hline 8 & 42.500 & 4 & 2.67 & 1133.33 \\
\hline 9 & 45.000 & 6 & 4.00 & 1800.00 \\
\hline 10 & 50.000 & 11 & 7.33 & 3666.67 \\
\hline 11 & 60.000 & 6 & 4.00 & 2400.00 \\
\hline 12 & 65.000 & 2 & 1.33 & 866.67 \\
\hline 13 & 75.000 & 3 & 2.00 & 1500.00 \\
\hline 14 & 80.000 & 4 & 2.67 & 2133.33 \\
\hline 15 & 85.000 & 3 & 2.00 & 1700.00 \\
\hline 16 & 100.000 & 3 & 2.00 & 2000.00 \\
\hline & Amount & 150 & 100.00 & 33400.00 \\
\hline
\end{tabular}

The WTP value obtained will produce information about how much farmers receive the AUTS program made by the government through the implementation of Law No. 19 of 2013. The insurance premium for cows is $2 \%$ of the insured price of IDR 10,000,000 per head. which is IDR 200,000 per head per year. The amount of premium assistance from the government (subsidies) is $80 \%$ or IDR 160,000 per head per year and the rest is independent from farmers of $20 \%$ or IDR 40,000, per head per year. Based on Table 5 . above, it can be seen that the largest percentage of WTP of respondent breeders is in the class of IDR 25,000. The estimated average value of WTP (EWTP) of IDR 33,400 / head / year, which is $83.50 \%$ of what the farmers have paid. This value is below the current premium value, which is an average of IDR 40,000 / head / year. This shows that farmers still want subsidies from the government for the implementation of AUTS.

Almost the same as [31] research that $96 \%$ of dairy farmers in Getasan District are satisfied with the AUTS program, although payments are often delayed, the amount paid is not commensurate with the risks experienced, most farmers still expect the program to be continued in the future.

However, for further implementation, improvements are needed. The success of the livestock insurance program is largely determined by the level of farmers' resources, experience in raising livestock, the readiness of insurance companies to collaborate with interested parties, and marketing [15]. 


\section{Conclusion}

The WTP value obtained shows that it is still below the value of the premium paid at this time, this indicates that farmers still want subsidies from the government for the implementation of AUTS to minimize the risk of livestock business. For further implementation, improvements are needed, the level of farmers' resources, experience in raising livestock, the readiness of insurance companies to collaborate with interested parties, and marketing.

\section{References}

1. S. S. Abidin, Kebijakan Publik (Salemba Humanika, Jakarta, 2012)

2. S. Rusdiana., Soeharsono, FPAE., 35 (2018)

3. N. Ilham., Saptana., A. Purwoto., Y. Supriyatna., T. Nurasa, PSEKP., (2015)

4. Hasnudi, Research and Development Agency of North Sumatra Province., (2009)

5. Directorate General of Livestock and Animal Health, (2010)

6. I. Susanti., A. Daryanto., Muladno, J. Man and Agr 9 (2012)

7. Directorate General of Livestock and Animal Health, (2019)

8. Directorate General of Livestock and Animal Health, (2017)

9. A. H. Haddi., M. B. Rombe., Fahrul, J. Agr Pet.10 (2011)

10. J. Atmakusuma., Harmini., R. Winandi, JRKPL, 1 (2011)

11. R. Widiati, Wartazoa, 24 (2014)

12. Ashari., N. Ilham., S. Nuryanti, AKP, 10 (2012)

13. Suharno, M Pet Kes Hew, (2017)

14. S. Wahyuni, (PASEKPE, Bogor, 2007)

15. N. S. An-Nisa., R. Syarief., G. Suprayitno, J. Man and Agr 12 (2015)

16. BPTP Kepulauan Bangka Belitung, (2018)

17. Regulation of the Minister of Agriculture of the Republic of Indonesia 40/Permentan/SR.230/7/2015

18. Regulation of the Minister of Agriculture of the Republic of Indonesia 12/KPTS/PK.240/04/2017

19. D. Field., Gillespie, J Agric and App Eco., 40 (2008)

20. M. Boyd., J. Pai., L. Porth, J Agri Fin Riv 73 (2013)

21. M. A. Khan., M. Chander., D. Bardhan, J Trop and Anim Health Prod 45 (2013)

22. Saptana., A. Daryanto., H. K. Daryanto., Kuntjoro, J Man and Agr 7 (2010)

23. J. A. Ramasubramanian, (The NEUDC, Darmouth College, USA 2012)

24. A. Falola., O. E. Ayinde., B. O. Agboola, J of Food and Agric Eco., 1 (2013)

25. G. T. M. Kwadzo., J. K. M. Kuwornu., I. S. B. Amadu, Research in App Eco. Macrothink Institute 5, (2013)

26. J. Sundar, L. Ramakrishnan, Int J of Business and Man Inv., 2 (2013)

27. Otoritas Jasa Keuangan., IV (OJK, Jakarta, 2019)

28. D. Besanko., R. R. Braeutigam, (John Wiley and Sons, Inc. New Jersey, 2002)

29. S. Dercon., M. Kirchberger., J. Gunning., J. Platteau, Literature review on microinsurance. (Retrieved from, Geneva, 2008)

30. A. Patt., P. Suarez., U. Hess, Global Environmental Change, 20 (2010)

31. F. I. Nadhila., W. Sumekar., A. S. Prasetyo, J. Agribest 5 (2021) 